\title{
INTEGRATED MANAGEMENT ANALYSIS OF INNOVATION: A CONCEPTUAL AND METHODOLOGICAL FRAMEWORK
}

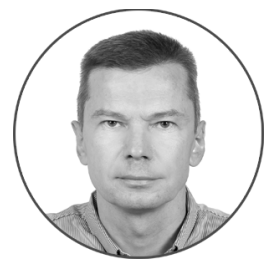

Article history:

Received 21 June 2018

Received in revised form

5 October 2018

Accepted 19 October 2018

Available online 24 December 2018

JEL classification: L29, M19, M49

Keywords: innovation, management, management analysis, integration, Balanced Scorecard

\author{
Sergei I. KRYLOV \\ Ural Federal University named after the First President of Russia B.N. Yeltsin, \\ Yekaterinburg, Russian Federation \\ 19016708@rambler.ru \\ https://orcid.org/0000-0001-6750-085X
}

\begin{abstract}
Subject The contemporary market economy has no alternative but to go down an innovation development path, necessitating the research into the theory, methodology and methods of innovation in management analysis. This facilitates adequate and effective decisions concerning innovation management.

Objectives The research reviews a conceptual and methodological framework for integrated management analysis of innovation, which constitutes an absolutely new kind of management analysis revealing the robust information about the innovation-driven performance, untapped resources and opportunities for their mobilization.

Methods The methodological framework builds upon a conceptual approach to integrating innovative processes, conceptual basis of business-specific types of management analysis to study innovation, and the Balanced Scorecard concept (namely, its innovation component).

Results The integrated management analysis of innovation is showed to comprehensively study the formation of relevant resources, costing, outcome of innovation, and crucial processes relating to consumers and competitors. The set of indicators includes metrics of innovation, investment, competitive and market analysis, which may serve for examining the innovative performance from operational, tactical and strategic perspectives. The integrated management analysis of innovation comprises the assessment, evaluation and estimation of indicators.

Conclusions and Relevance The integrated management analysis of innovation is a fairly effective tool to supply the managing process with necessary information since it views innovation as a single construct.
\end{abstract}

(c) Publishing house FINANCE and CREDIT, 2018

The editor-in-charge of this article was Irina M. Vechkanova

\section{Introduction}

As we can see from the experience of developed countries, the high level of economic development depends on a number of conditions, with the accumulated scientific, technical, industrial and investment potential, institutional factors of the technological progress and State support of innovative transformations being the main ones.

The contemporary market economy has no alternative but to go down an innovation development path, which boosts the need for research into the theory, methodology and methods of the innovation

${ }^{\dagger}$ The English text was provided by the author. component of management analysis. This, in turn, makes it possible to take adequate and effective decisions as regards innovation management by an economic agent (entity).

The innovation development concept is gradually turning into a focal point of most natural and technical branches of science and humanities. Economics plays a special role in studying the diverse effect of innovations on various aspects of life in the contemporary society. The existing need to speed up the transition of a particular country to an innovation-driven economy calls for the intensification of research into innovative development issues. This forms and strengthens 
competitive advantages of each economic entity in the contemporary changing world, which is one of the key tasks in ensuring its survival and prosperity. The innovative level and innovation efficiency that the economic entity has achieved largely determines whether the task is effectively addressed. Competition entices economic entities to ensure economic viability both through a more reasonable use of production and financial resources and by attracting investors to renovate and expand business. This is preceded by innovation activities aimed at developing capital investment options designed to reveal and support competitive advantages. Such advantages mean fewer risks, higher return on investment as compared to rivals in a specific market niche. The market niche may mean a particular kind of activity aimed at creating consumer values, or a geographic area, but in any case potential business propositions need to be substantiated in terms of innovation on the basis of a clear information database and convincing analytical calculations.

The importance of the above issues requires to improve an analytical support of the managerial decision making process as regards innovation (in its broad sense, that is, including investment and marketing), which, in my opinion, is the most important part of an organization's economic activities under the current conditions.

In view of the above mentioned, I suggest using integrated management analysis of innovation that I have designed as a tool to provide an analytical support in innovation management.

\section{The Methodology of Research}

The methodological framework of the research summarized herein is based on the following elements:

1) a conceptual approach to the integration of processes that make up the organization's innovation activity;

2) the conceptual principles of business-specific kinds of management analysis used to study innovation;

3) the Balanced Scorecard concept (its innovation component).

Let us take a brief look at each of them.

According to my own definition, innovation is the process of finding and using S\&T achievements with the help of R\&D efforts which make it possible to create and introduce innovations that result in certain effects inside the company and/or in the domestic and/or foreign market.

As for the place and the role of innovation in the contemporary market economy, the assessment of integrative processes in the field of innovation acquires critical importance. The problem is that innovation yields the maximum effect if it is closely integrated with investment, creation of new production facilities, design and financing. If so, it not only reduces the general innovation cycle but also triggers a synergistic effect, i.e. an additional effect caused by close partnership of all the parties involved in a single technological treadmill.

The development of science and innovation appears to call for joining the efforts of scientists, those developing innovations, designers, investors, developers and builders in the course of implementing the so called integrated innovation activity. In other words, today's situation requires a fundamentally different interaction pattern for all participants to the single technological treadmill, and the development of integration processes in innovation should be encouraged in every possible way.

Consequently, effective innovation management is only feasible if this activity is regarded as a single complex. As a result, all economic functions of management (accounting, analysis, planning, etc.) also become integrative by nature.

It is natural that the strongest synergistic effect is achieved in an integrated system where the entire complex of processes of development, creation and use of innovation objects of capital investment is implemented in the form of a single innovation project.

Effective management of such a project calls for the development and application of methods, procedures and indicators of management analysis. The distinguishing feature of contemporary management analysis lies in its influence on the process of accounting so as to obtain relevant analytical information.

A broader interpretation of the notion management accounting by Ch. Horngren and J. Foster [1] may be of interest to researchers: it implies the identification, measurement, collection, systematization, analysis, decomposition, interpretation and communication of information needed for a management system. In this case management analysis is understood as a component of management accounting. 
Some authors, for example, C. Drury [2], imply that management analysis is part of management accounting and refer to the definition of the latter as a system for providing relevant information for managers to make more substantiated management decisions inside a particular economic agent in order to boost the performance of current operations and overall effectiveness of its activity.

The contemporary theory and practice of management analysis have various approaches to its classification [3-5].

Moreover, some understand the term classification not as an elaborate scheme that distinguishes 10 businessspecific kinds of analysis [6], but as a way of distinguishing relevant kinds of management analysis based on object-functional characteristics aiming to use the opportunities of their integral inclusion for a synergistic effect. As a result, any required number of analysis types can be singled out, which allows to use a new approach to economic processes based on the integration of techniques pertaining to different kinds of analysis.

For a better understanding of specific features of the proposed classification, we consider it useful to define in reasonable detail the following characteristics of each business-specific kind of corporate management analysis (Table 1): the object of analysis, subject of analysis, goal of analysis, and main information sources.

With this in mind, the proposed goal setting includes such steps as assessment, evaluation and forecast of indicators characterizing resources, costs and results of the corresponding type of corporate activity. When analyzable indicators are assessed, their factual and baseline values (targets, values of prior period) are juxtaposed, the deviation of actual values from baseline values is identified and quality of those deviations is assessed. Evaluating the deviations of the analyzable indicators reveals factors that brought them about while relevant techniques of factor analysis help determine the effect of each one. In forecasting the indicators under study, multiple options are offered through relevant forecasting methods depending on expected changes in internal and external conditions of the company's operation. It is obvious that assessment, evaluation and forecasting are closely interrelated as each subsequent action is based on the preceding one. For example, the evaluation results from the assessment of indicators while forecast stems from the outcome of the evaluation.

The Balanced Scorecard Concept (BSC) as an instrument applied in strategic management was developed by the U.S. scientists R. Kaplan and D. Norton in the early 1990s [7]. The concept evolved both in their works [811] and proceedings of some other foreign economists [12-17]. The concept has proven its practical viability.

Generally speaking, the Balanced Scorecard can be characterized as a system of parameters describing the overall performance of an organization in the contemporary market economy.

The fact of being called Balanced Scorecard reflects the balance between short-term and long-term goals, financial and non-financial indicators, basic and auxiliary parameters, as well as internal and external factors of business operation.

The main purpose of the Balanced Scorecard is to transform the company's strategy into specific tangible objectives, indicators and, eventually, actions (measures).

The Balanced Scorecard system is based on the causeand-effect relationship, factors of achievement and interrelation with financial indicators.

The Balanced Scorecard comprises four basic interrelated elements - financial and customer perspectives, components relating to internal business processes and those ones dealing with staff training and development. The components are represented in the light of key problems, strategic objectives, indicators and their target values as well as strategic measures. In addition, the component of internal business processes consists of other three elements, i.e. innovation, operational and after-sale service.

The BSC metrics allow to comprehensively characterize the performance of both commercial, government and non-profit organizations. The metrics are relatively few in numbers (about 25 scores on average) and they are formed with the vision and strategic goals of any particular organization, which means they have individual features. They represent the balance between external accounting data for owners (stakeholders) and clients and internal characteristics of the most significant business processes, innovations, training and growth. This is the balance between results of the organization's previous performance and future growth. The system constitutes a combination of 
objective, easily measurable results and subjective, somewhat arbitrary parameters of the future growth.

In other words, when describing the corporate strategy, the BSC serves as a mechanism for implementing this strategy, rather than a mechanism for defining it. The Balanced Scorecard is not only a tactical or operational assessment system. It does not replace the routine parameter assessment system. The BSC metrics are selected in such a way so as to make managers and employees focus on the factors that will significantly drive the company's ability to compete in the market. At the same time, the BSC should be available as an information source to employees at all levels.

For innovation companies the BSC serves as a means of long-term strategic management while its assessment component is used to solve the key tasks of the management process.

The innovation component of the Balanced Scorecard can be presented as Table 2 .

Just like any other BSC metric, the indicators of its innovation component are always specific to any particular organization and determined by the corporate innovation strategy. Nevertheless, to illustrate this, we will highlight several common metrics of the innovation process that characterize its strategic goals, being mostly versatile for all kinds of organizations (Table 3).

As showed in my previous publications, the metrics of the BSC innovation component may be used as a database for strategic innovation analysis in any company which uses the Balanced Scorecard [18]. Such analysis constitutes a part of strategic management analysis and consists of assessment, evaluation and forecasting of certain metrics $[19,20]$.

Having determined that the development of integration processes in innovation is possible, necessary and viable and revealed an objective need to possibly combine the analysis of this activity with some of the most important kinds of management analysis, including strategic management analysis, we shall proceed to the conceptual basics of an absolutely new kind of management analysis - integrated management analysis of innovation.

\section{Results}

When characterizing the most important organizational and methodological issues relating to a fundamentally new kind of management analysis - integrated management analysis of innovation - one should keep it in mind that this kind of analysis is, first and foremost, aimed at uniting innovation management analysis and investment management analysis. It is therefore reasonable to link the result of this integration, that is, innovation and investment management analysis, to competitive management analysis and marketing management analysis.

In my opinion, programme and methodological questions relating to integrated management analysis of innovation should be strictly considered in the following sequence: identify the object and subject $\square$ identify goals and principles of analysis $\square$ develop a system of indicators $\square$ select information sources $\square$ select methods of analysis $\square$ determine areas of application of the results.

\section{Identification of object and subject of integrated management analysis of innovation}

When identifying the object and subject of integrated management analysis of innovation (the first programme-methodological question), I propose the following definitions.

The object of integrated management analysis of innovation is the innovation activity (in a broad meaning of the word, that is, including investment) of companies which have opted for an innovative development path or continue the transition. In such companies, innovation and investment activities are integrating irreversibly. Therefore, it seem extremely unreasonable to conduct innovation management analysis separately from investment management analysis and further integrate the results.

The subject of integrated management analysis of innovation is a set of processes constituting the formation of relevant resources, costs incurred and results obtained during the analyzable activity. The results, costs and efficiency of resource use are largely determined by:

- the extent to which the scale and structure of innovation corresponds to the current and, in particular, future needs of the market of innovation products and technologies,

- the competitiveness of innovation (as compared with competitors).

In the light of the above mentioned, the subject of integrated management analysis of innovation should also include the most important processes happening 
in the consumer market and the company's competitive environment.

\section{Identification of goals and principles of integrated management analysis of innovation}

Goals and methodological principles of integrated management analysis of innovation shall be set (the second programme-methodological question) after the main goal and more local goals it consists of are identified.

While the company transits to the innovation economy, the main goal of integrated management analysis of innovation is to provide top management and owners with complete, accurate and quality information about the company's innovation-driven performance, untapped resources and opportunities for their mobilization.

The main goal of integrated management analysis of innovation consists of local goals (subgoals) connected with the relevant kinds of management analysis. These subgoals may be defined as follows:

- in the case of innovation management analysis, revealing the scientific and technical level, progressivity ratio and commercial demand for innovations as well as the innovation activity and how the innovation activity is encouraged in the company;

- in the case of investment management analysis, assessing if the company has enough investment resources, financial support of the innovation activity from budgets of all levels, domestic and foreign capital, and evaluating the efficiency of investments in innovations;

- in the case of competitive management analysis, assessing the competitiveness, intensity of innovation creation, saturation of the company with innovation, its technological dependence, duration of the innovation completion cycle and copyright protection of innovations;

- in the case of marketing management analysis, assessing the integrity of innovative product development, use of the latest and emerging technologies, demand for innovation of processes, and ubiquitous approach to the use of innovative processes.

The strict adherence to the system of local subgoals allows to implement the main goal of integrated management analysis of innovation.
To increase the scientific level of integrated management analysis of innovation, it is essential to determine the principles for applying it during analytical procedures.

Specific principles of integrated management analysis of innovation include:

1) the key link principle in partially integrated analysis;

2) the principle for prioritizing the corporate innovation activity in terms of transit to the sixth wave of innovation.

These are basic characteristics of principles for the integrated management analysis of corporate innovation.

\section{The key link principle in partially integrated analysis}

It is relatively simple to select the key link at the initial stage of integration procedures. If the object of these procedures is a modern university, all business-specific kinds of analysis subject to integration are characterized by long planning horizons because of the lengthy process of professional training. Therefore, it is strategic management analysis that will play the main role in the integration.

The task becomes somewhat more challenging with a more complicated, partially integrated object of analysis, for example, the innovation activity (including investment activity). The integration of these two kinds of activity is unbiased and fast. The invest-all-ininnovation principle gains momentum in the area.

Given the above mentioned, four local kinds of management analysis of innovation (innovative, investment, marketing and competitive) are not completely equal. Their integration is based on innovation management analysis which corresponds with the integrated character of the relevant kind of activity. That is why capabilities of investment management analysis, marketing management analysis and competitive management analysis are partially used in innovation management analysis, rather than being completely absorbed by the latter kind of analysis.

\section{The principle for prioritizing the corporate innovation activity in terms of transit to the sixth wave of innovation}

As seen in numerous definitions of innovation in contemporary economic literature [21-24], most authors consider innovations to comprise not only 
brand new novelties but also different kinds of improvements and modifications, the existence of which tends to blur boundaries between innovative and non-innovative products.

In my opinion, innovative products driving the company to the sixth wave of innovation must be a priority in the innovation activity.

The basic discoveries and inventions as part of the sixth wave of innovation result from a qualitative breakthrough in improving the key factor and the core of the fifth wave of innovation, which includes microelectronics, software development, radio engineering, machine building, information and communication technologies, laser technology. Considering the existing rate of long-term technical and economic development, a steady growth in the currently prevailing fifth wave of innovation is about to reach its ceiling, unveiling the general outlines of the sixth wave of innovation. The boundaries between fundamental technologies (biotechnology, nanotechnology, material engineering and IT) are getting increasingly blurred. The role of nanotechnology is especially important as it will power a breakthrough to new horizons of computer science, molecular biology, genetic engineering and medicine.

\section{Developing a system of indicators for integrated management analysis of innovation}

Based on the above mentioned considerations, a system of integrated innovation indicators was developed using the existing statistical practice of accounting in this field and non-accounting sources.

The most important and pending methodological issue of integrated management analysis of innovation (both for the purposes of research and application) is the information and analytical support of management. The main barrier is the lack of a well-tested system of indicators, which constitutes the third problem of integrated management analysis of innovation performance.

Constructing an analytical system of indicators is technically difficult because of the complexity of 'merging procedures' as part of integrated analysis. First, indicators that belong to different types of management analysis (innovation, investment, market, and competition) are to be considered jointly. Second, it is very desirable to use the same (structurally identical) indicators for measurement, cost engineering, planning and forecasting as it would make it possible to reduce the workload on analysts, planning specialists and cost engineers.

I believe that among the variety of innovation indicators the priority should be assigned to those ones having scientific and technological impact, competition, quality, complexity and commercial potential.

It seems advisable to consider the proposed metrics, first of all, as homogeneous groups (within the limits of specific areas of management analysis), and, second, to differentiate the analytical metrics by three phases of innovation - creation, adoption and outcome [25-26].

Having grouped the metrics by specific areas of management analysis for the purposes of its further integration, I build a scorecard comprising 21 key indicators that form four groups. The scorecard (Table 4) allows to comprehensively assess innovation performance in a company.

Let us focus on each group of indicators.

The first group includes five analytical indicators of innovation analysis per se. They primarily characterize the scientific and technological level of innovations being created.

The progressivity indicators of innovation (1.1) reflect the percentage of forward-looking process/product innovations in the total number of process/product innovations created by the company.

The S\&T indicator of introduced innovations (1.2) shows the share of new (that is, excluding upgrades and modifications) product innovations in the total number of product innovations.

The indicator of innovation activity (1.3) is the percentage of the total number of innovative products, i.e. new, upgraded and modified ones in the company's output.

The indicator of the commercial demand for innovation (1.4) is calculated as the average number of licensing agreements per process/product innovation.

The indicator of incentives to innovate (1.5) is the ratio of net income from innovation (in its broadest sense) to the company's payroll in the innovative business unit.

The above indicators of innovation analysis primarily reflect the scientific and technological level of innovation, its commercial value and monetary incentives in innovation. However, it is not enough to 
rely on them only to advance innovation at the corporate level and succeed in this field if due attention is not paid to competitors' achievements. For this purpose, it is necessary to resort to competitive analysis that relies upon the competitive intelligence, seeking to reveal the strengths and weaknesses of the main competitors.

The second group of analytical indicators - competitive analysis metrics - contains six items.

The competitiveness indicator (2.1) is the weighted average score reflecting the competitiveness of innovative products, which is calculated by the percentage of innovative products of any competitiveness in the total sales of innovative products and score of each competitiveness level.

The indicator of innovation intensity (2.2) shows the total number of created process/product innovations per innovator.

The indicator of process innovation density (2.3) is determined by dividing the number of process innovations in use by the total number of all technological processes.

The indicator of technological dependence (2.4) is the ratio of process/product innovations used (adopted) under licensing agreements to the total number of process/product innovations.

The indicator of legal protection for innovation (2.5) is computed as the ratio of the number of product innovations protected with at least two copyright certificates (a patent for an invention, a utility model, a patent for an industrial design, or a trademark certificate) to the total number of created product innovations.

The indicator of the innovation duration (2.6) reflects the mean time (years) needed to create (use, master) process/product innovations.

The indicators of competitive analysis characterize solely corporate relations with its existing and potential competitors and resulting adjustments to the innovation strategy. It is therefore necessary to supplement competitive and innovation analysis with market research data.

The third group of indicators - those of market analysis - consists of four analytical indicators.

The indicator of the comprehensive development of product innovation (3.1) is the ratio of the number of product innovations that are compliant with key requirements (environmental, after-sale service, and security) to the total number of created product innovations.

The indicator of the advanced technology use (3.2) is the share of the advanced technology groups in the company that use process innovations in the total number of advanced technology groups.

The indicator of demand for process innovation (3.3) is the ratio of the number of process innovations that created and used by an analyzable company to the total number of process innovations created by the company and used by other companies in the industry.

The indicator of versatile applicability (3.4) is calculated as the ratio of the application scope of process/product innovations to the total number of the consumption segments in the national economy.

The above indicators of market analysis reflect the sustainability of the innovating company in the innovation market.

The fourth group of indicators - those of investment analysis - includes six analytical indicators.

The indicator of financial aid from the State (4.1) is the ratio of funds received from the government to total spending on innovation from all financial sources.

The indicator of the company's reliance on commercial loans (debt ratio) (4.2) is the ratio of commercial loans for innovation to total spending on innovation from all financial sources.

The indicator of the company's financial independence (4.3) is the ratio of equity earmarked for innovation to total spending on innovation from all financial sources.

The financial indicator of technological dependence (4.4) is the ratio of procurement expenditures on innovations under licensing agreements to total expenditure on innovation.

The indicator of foreign equity (4.5) is the ratio of foreign capital invested in innovation to total investment in the company's innovation.

The indicator of national equity (4.6) is the ratio of domestic investment in innovation to total investment in the company's innovation.

The investment analysis indicators disclose sources of funding and investment in innovation in an analyzable company. 
In my opinion, the proposed system of the key indicators of integrated management analysis of innovation (Table 4) is versatile to a large extent, being practicable for examining operational, tactical and strategic aspects of innovation in almost any entity. The system implies that the indicators are assessed, evaluated and projected at the end of every month, at the end of every year, and for the effective period of the strategy being developed respectively.

However, when conducting integrated management analysis of innovation, the strategy should accommodate to corporate distinctions, thus requiring to supplement the above system of indicators with innovation indicators of the company's Balanced Scorecard. The most general ones are given in Table 3.

\section{Selecting sources of information for integrated management analysis of innovation}

When addressing the programme-methodological issue so as to determine what forms, methods and sources are appropriate to collect necessary data, it is advisable to apply the so called unformalized data collection methods [4, 27].

In my opinion, the main sources of information for integrated management analysis of innovation are:

- up-to-date statistical reports;

- management accounting data;

- findings of an expert opinion poll among the most competent professionals in an analyzable industry;

- findings of the competitive intelligence;

- findings of surveys among clients and consumers.

The first two sources of primary data are traditional and more credible than the other three, which are considered unformalized sources of information.

It should be kept in mind that modern techniques for applying unformalized data collection methods for purposes of the analysis have grown very sophisticated. Practical specifics of a dedicated expert survey among high professionals is thoroughly described in scholarly literature [28].

Competitive intelligence is a crucial source of primary information for integrated management analysis of innovation.

Competitive intelligence is supposed to examine the competitive environment, purposefully gather a certain information about competitors so as to make decisions about the strategy and tactic of doing business [29].

Competitive intelligence is

1) collection and processing of data from various sources to make decisions and improve the competitive advantage of a profit-making entity. Unlike industrial espionage, competitive intelligence is performed legally and in compliance with ethical standards;

2) the structural unit of a company that performs the above functions;

3) a set of measures aimed at providing the information and analytical support to managers through specific data collection methods so that they get a deep understanding of the current position of competitors and development trends in their operation.

As part of competitive intelligence, the statics and dynamics of the competitors' innovative business are analyzed using publicly available and partially restricted information. Findings of such analysis should be delivered to the company management and stakeholders on a timely basis.

The outcome of customer and consumer surveys and the first two sources of primary information are treated as traditional, revealing the demand for new products and services that will be valuable for customers and consumers in terms of price, quality, functionality, image, reputation, relationship and service [8].

\section{Selecting methods for integrated management analysis of innovation}

As for the selection of methods for integrated management analysis of innovation (the fifth methodological issue of integrated analysis), it should be noted that any of the six classification groups is acceptable [27].

1. Unformalized (logical) methods are based on the logical description of analytical procedures, rather than the use of rigorous analytical dependencies. They include methods of expert assessment, scenarios, psychological and morphological comparison, scorecards, systems of analytical grids, etc. Such methods are biased due to the analyst's intuition, experience and expertise.

2. Elementary methods for microeconomic analysis aim to analyze the company's performance and identify a capabilities for improvement. Factor analysis 
methods (tools) is of special significance in this group. These are replacement chain methods, arithmetic differences method, method for identifying the isolated influence of factors, differential, logarithmic and integral methods.

3. Traditional methods of economic statistics are designed to quantify phenomena and processes. They are specifically adapted to research into social and economic systems. They have a great scope of application in all branches of microeconomic analysis. These are the arithmetic mean, grouping method, basic time series methods, indexing method. They are conventionally referred to as traditional because of their predominance, simplicity and historical background.

4. Mathematical and statistical methods (stochastic modeling) rule out the recurrence of the required phenomenon to forming the totality, which is typical of experiments. Correlation between individual factors and indicators is extremely high. It is not always possible to model the required situation. The analyst should, therefore, have a very clear idea of the conventionality of quantitative estimates yielded by such methods and should not overemphasize them. By using these methods correlation and regression analysis, dispersion analysis, cluster analysis, methods of modern factor analysis, methods of space-time totality processing, it is possible to predict the dynamics of the key indicators, develop scientifically proven standards and identify the most significant factors.

5. Decision making methods are used when the same person is responsible for justifying a decision analytically and making it. This requires to master techniques that were developed as part of the decision theory: situation analysis and forecasting, imitation modeling, decision tree, linear programming, uncertainty analysis.

6. The methods of financial computing (discounting and compounding, cash flow analysis) are based on the time value of money. They help make managerial decisions that prove to be effective in the long run. Decision makers and analysts, who assist them, must be capable of doing such computing.

\section{Application scope of findings of integrated management analysis of innovation}

Analytical findings (first of all, a set of metrics for innovation, investment, marketing and competitive analyses) can be applied at various tiers of the governance hierarchy, thereby reinforcing the scientific underpinning of projections, concepts, strategies and development programs and improving innovation management (in its broadest sense) in a company (industry or region). The results also seem useful for furthering the theory and methodology of economic analysis.

The analytical findings can be applied in the key areas as follows.

1. As a contribution to the theory and methodology of economic analysis.

1.1. Substantiating a choice of alternative innovation projects, which are compliant with certain criteria of activity-specific analysis.

1.2. Revealing capabilities for unformalized analysis methods as part of integration procedures and selection of the most successful innovation project.

2. As an improvement to the information and analytical support of decision making in management.

2.1. Comprehensive assessment of the current condition of innovation, innovation trends and development factors.

2.2. Identifying untapped reserves and growth opportunities.

2.3. Developing a set of extrapolating and exploratory benchmark-based forecasts as part of short-, mid- and long-term planning.

2.4. Articulating development concepts and improving innovation management in the foreseeable future.

2.5. Outlining alternative strategies for reaching innovation goals.

2.6. Designing regional special-purpose programs of governmental support to priority innovation development.

2.7. Setting up a system of indicators and innovation monitoring.

Let us dwell upon some of the key areas for using the analytical findings.

To substantiate a choice of alternative innovation projects, which are compliant with certain criteria of activity-specific analysis, it is necessary to assess innovative projects the company plans or borrows in terms of a local kind of management analysis as per 
relevant metrics. For example, when innovation analysis is performed, the following criteria of the project success are applied: innovation progressiveness, S\&T level, commercial viability.

When investment analysis is performed, investment project success criteria include the equity-to-assets ration of the company in financing the innovation, financial indicator of technological dependence, relative investment per innovative product, etc. Marketing specialists in charge of marketing analysis pay much attention to the market share of a new product, its development complexity and its usability, etc. Competitive intelligence officers and analysts go for the competitiveness metrics, legal protection of innovations, development time, etc.

Whereas it is possible to identify capabilities of unformalized analysis methods in implementing integration procedures and selecting the most successful innovation project, this is indicia of an idiosyncratic algorithm for integrating findings of activity-specific types of management analysis. The algorithm implies the expert panel method and procedures for reconciling experts' opinions on the degree of alternative innovation project success.

Comprehensive assessment of the current innovation, trends and development factors is based on a specially designed scorecard of integrated management analysis that contains 21 indicators (Table 4) and addresses the above questions.

Identifying untapped reserves and opportunities for innovative growth is a logical step to continue and develop the previous scope of application. For example, if the innovation activity indicator, which is measured as the ratio of the total number of innovative products to the company's output, is lower in the reporting period than in the baseline period, then obviously there are untapped reserves for improvement. If the indicator of innovation activity that is measured as the proportion of fundamentally new innovative products, is much lower than the previous indicator, the company has reserves for spurring its innovative growth.

A set of extrapolating and exploratory normative projects for short-, mid- and long-term planning is developed before a concept and strategy for the company's innovative development is created. The projections are an essential element of information and analytical support of appropriate decision making processes.
In developing concepts for the development and improvement of innovation management in the foreseeable period, an integrated analysis of this activity provides reliable scientific grounds for substantiating the mission, goals and objectives of the company's development for an extended period of time. One should bear in mind that the scientific validity of the concept increases if the overwhelming majority of the known activity-specific types of management analysis are used as the most comprehensive integrated analysis, rather than separately.

In outlining alternative strategies for attaining innovation goals, it should be remembered that the strategy requires to specify the company's development in much more detail than the concept. Moreover, unforeseen (at the stage of strategy development) changes in external and internal operational conditions may occur during the strategy implementation. So, unlike the concept, several alternative development strategies are usually created. The role of innovation analysis can hardly be overestimated.

In preparing targeted regional programs of State support to priority areas of innovation, integrated management analysis (especially its innovation and investment components) enables government agencies to identify the most promising trends in innovative development and provide them with extensive support.

In setting up a system of indicators and innovation monitoring, it is extremely important to select appropriate indicators and make sure that monitoring is done on a regular basis. Otherwise companies will unavoidably adopt an innovation-based development model any time soon.

\section{Discussion}

I believe that the findings associated with the creation of the conceptual framework for integrated management analysis of innovation as a brand new type of management analysis that allows to study innovation in its broadest sense are unprecedented and can therefore be considered as new and unique.

In the mean time, it is unreasonable to overlook the existing research into the analysis of innovation, which was conducted by the most prominent scholars and experts.

I suggest reviewing some of them. 
R. Kaplan and D. Norton characterize innovation as one of the most critical internal business processes and point out two components [8]: the identification of the market and creation of the product (service). Hence they indicate two steps in analyzing the innovation process. As part of the first step, the analysis should answer two questions adequately and accurately:

1. What top values will the customer pursue tomorrow?

2. How does innovation allow to detect competitors delivering such goods and services?

This analysis could be measured with the number of entirely new products and services developed, success in developing specific products and services to target customer groups, or just the preparation of market research into the future customer preferences. These metrics forerun the second step of the analysis that consists of three elements:

1) basic research to develop brand new products and services for delivering value to customers;

2) applied research to employ the existing technology for producing the next generationproducts and services;

3) focused development efforts to bring new products and services to market.

J. Pearce II and R. Robinson largely associate the analysis of innovation with the study into two types of risk triggered by innovation: market and technological risks [30]. Market risks arise from uncertainty as to the existence of a market niche for a new product or service, its size and pace of the market growth, which raises concerns as to whether anyone is going to buy them. Technological risks are caused by the uncertainty of technological development, complexity of creating technical standards and generally accepted models: which of the available technologies will actually work? Technological risks are of critical significance to innovative products, while market risks matter to business models and processes. In analyzing innovation risks, it is necessary to research the market and new applications for the existing technologies.

According to C. Christensen and M. Raynor, the analysis of the innovation process will make it more predictable as it answers the following key questions [31]. How can we win the most powerful competitors? What products will customers want to buy? Who are the best customers for our products? How should the scope of the business be properly defined? How should the loss of product identity be avoided? How should the company develop its subversive activities? How should the strategy development process be managed? What sources of funding shall be used? What contribution do top managers make to promote a new business?

R. Grant proposes analytical principles to ensure a higher efficiency of the strategic management of innovation [32]:

- evaluating the potential for an innovation to create value;

- assessing the relative advantages of licensing, alliances, joint ventures and internal development as strategic options for exploiting innovation;

- identifying the relative advantages of being a leader or a follower in innovation.

R. Grant also underlines the fundamental dilemma of innovation since innovation is an unpredictable process that requires the favorable organizational background, while the strategy is about making decisions on the allocation of resources. Obviously, it should be taken into account when performing the strategic analysis of innovation.

According to G. Hamel, the analysis of each innovation process as part of innovation management is confined to the following questions [33]. Who owns the innovation process? Who has the power to change it? What are success metrics? Who applied for the innovation process? Who will participate in the innovation process? What are inputs or data of this process? What analytical tools are used? What events and milestones drive this process? What kind of decisions does this process generate? What are decision-making criteria? How are decisions communicated? Who are the decisions communicated to? How does this process link to other management systems?

After documenting the details of each innovation process, interested parties such as the process owner, regular participants, and anyone else who might have a relevant point of view, are summoned. They assess the process in terms of its impact on a management issue the company is tackling.

Having summarized the above opinions of some leading scholars in innovation management, I would like to point out drawbacks of their innovation analysis concepts. 
1. As a rule, innovation analysis implies relevant questions are addressed using seemingly unformalized methods, while there is no conceptual approach to conducting the analysis.

2. Innovation research issues may be diverse by nature depending on researchers' preferences and assumptions (marketing, technology, finance, management). They primarily focus on market research into innovation, thus hampering a comprehensive analysis.

3. There is no generally accepted system of indicators (except for, perhaps, some general metrics of the innovation component of the Balanced Scorecard, which may be specific to a company since they depend on its strategy) and innovation analysis procedure.

The above drawbacks can hardly render an adequate information and analytical support for an effective decision making process in innovation management.

Referring to the assumption that effective innovation management is practicable when this area of business is viewed as a holistic system in which processes of development, creation and use of innovations form a single innovation project, I have created a conceptual framework for integrated management analysis of innovation. It allows to overcome, to a large extent, the above drawbacks and helps increase the effectiveness of innovation management.

I also worked out key methodological aspects of integrated management analysis of innovation (a system of analytical indicators including generally accepted analytical indicators (Table 4), as well as metrics of the innovation component of the Balanced Scorecard (Table 3), analysis procedures, main sources of information for the analysis, analysis methods, areas of application).

I therefore provide a more detailed, better reasoned and explained solution to the issue of improving information and analytical support to innovation management through the development of a conceptual framework of integrated management analysis of innovation as compared with other works on the subject. The proposed solution contributes to scientific knowledge about modern innovation management.

\section{Conclusions}

Having outlined the conceptual and methodological framework for integrated management analysis of innovation as a fundamentally new type of management analysis and, consequently, a new analytical tool of innovation management, I can make the following conclusions.

1. Effective innovation management is feasible only when this area of business is viewed as a holistic system in which the combination of development, creation and use of innovations form a single innovation project.

2. To manage such projects effectively, it is necessary to create and apply a new type of management analysis integrated management analysis of innovation.

3. The main purpose of integrated management analysis of innovation is to provide managers and owners of a company with complete, accurate and quality information about the effectiveness of its innovation-driven operation, untapped resources, and the possibility of their use.

4. The goal consists of activity-specific subgoals that are related to an activity-specific type of management analysis used to study innovation: innovation analysis, investment analysis, competitive analysis; market analysis.

5. A system of indicators of integrated management analysis of innovation incorporates indicators of innovation analysis, investment analysis, competitive analysis, and market analysis, which are largely versatile and can be used to scrutinize every aspect of innovation (operational, tactical and strategic) in almost any company.

6. If specific features of a company have to be taken into account when conducting an integrated management analysis of innovation from a strategic perspective, the above system of indicators is supplemented with the innovation component of the company's Balanced Scorecard.

7. Integrated management analysis of innovation includes the assessment, evaluations and forecast of indicators.

8. The analytical findings could be used not only to improve information and analytical support to innovation management, but also to further the theory and methods of economic analysis.

\section{Further Research}

The conceptual and methodological framework for integrated management analysis outlines the new area

Please cite this article as: Krylov S.I. Integrated Management Analysis of Innovation: A Conceptual and Methodological Framework. 
of research and practice and provides a sort of theoretical guidance for further development of this analytical tool for innovation management, especially in terms of its application.

There are several trends to follow in studying integrated management analysis of innovation:

1) expanding the system of key indicators of integrated management analysis of innovation (Table 4) and their further elaboration in pursuit of a greater accuracy of comprehensive research into innovative performance;

2) developing the criteria to evaluate the deviation of actual key indicators of integrated management analysis of innovation from their baseline values in terms of materiality;

3) setting up statutory values for each key indicator of integrated management analysis of innovation, and introducing a three-group classification (best, medium, worst);

4) creating a method to rank innovation performance through scoring by experts who use the key indicators of integrated management analysis;

5) forging specific methods for evaluating (factor analysis) and forecasting each of the key indicators of integrated management analysis of innovation;

6) devising a system of indicators and methods for integrated management analysis of innovation that would take into account features of industry-specific innovation in companies operating in different branches of the economy;

7) developing economic and mathematical models and software that would allow to use integrated management analysis of innovation for innovation management.

Table 1

Business-specific kinds of management analysis of an organization and its main characteristics

\begin{tabular}{|c|c|c|c|}
\hline \multicolumn{4}{|c|}{ Characteristics of analysis } \\
\hline Object & Subject & Goal & Sources of information \\
\hline \multicolumn{4}{|c|}{ Intracompany management analysis (analysis of production costs) } \\
\hline $\begin{array}{l}\text { All kinds of production } \\
\text { costs }\end{array}$ & $\begin{array}{l}\text { Production and economic } \\
\text { activities }\end{array}$ & $\begin{array}{l}\text { Assessment, evaluation and forecast of resources, } \\
\text { costs and results of production activities }\end{array}$ & $\begin{array}{l}\text { Financial and management accounting } \\
\text { data }\end{array}$ \\
\hline \multicolumn{4}{|c|}{ Management analysis in investment } \\
\hline Investment & Investing activity processes & $\begin{array}{l}\text { Assessment, evaluation and forecast of resources, } \\
\text { costs and results of investing activity }\end{array}$ & $\begin{array}{l}\text { Financial and management accounting } \\
\text { data }\end{array}$ \\
\hline \multicolumn{4}{|c|}{ Management analysis in innovation } \\
\hline Innovation & Innovation processes & $\begin{array}{l}\text { Assessment, evaluation and forecast of basic } \\
\text { elements of innovation activity }\end{array}$ & $\begin{array}{l}\text { Financial and statistical accounting, } \\
\text { sociological data }\end{array}$ \\
\hline \multicolumn{4}{|c|}{ Management analysis in logistics } \\
\hline Logistics & Logistic processes & $\begin{array}{l}\text { Assessment and evaluation of resources, costs } \\
\text { and results of logistic activity }\end{array}$ & $\begin{array}{l}\text { Financial and management accounting } \\
\text { data }\end{array}$ \\
\hline \multicolumn{4}{|c|}{ Management analysis at the organizational and technical level } \\
\hline $\begin{array}{l}\text { Material and technical } \\
\text { resources }\end{array}$ & $\begin{array}{l}\text { Renewal of material } \\
\text { and technical resources }\end{array}$ & $\begin{array}{l}\text { Assessment and evaluation of costs and results } \\
\text { of material and technical resources development }\end{array}$ & $\begin{array}{l}\text { Financial and management accounting } \\
\text { data }\end{array}$ \\
\hline \multicolumn{4}{|c|}{ Management analysis of social and labor relations } \\
\hline $\begin{array}{l}\text { Social and labor } \\
\text { relations }\end{array}$ & $\begin{array}{l}\text { Current social and labor } \\
\text { relations }\end{array}$ & $\begin{array}{l}\text { Assessment and evaluation of the current condition } \\
\text { and development of social and labor relations }\end{array}$ & $\begin{array}{l}\text { Financial and statistical accounting, } \\
\text { sociological data }\end{array}$ \\
\hline \multicolumn{4}{|c|}{ Management analysis of the economic potential } \\
\hline Economic potential & $\begin{array}{l}\text { Current economic potential } \\
\text { and its development }\end{array}$ & $\begin{array}{l}\text { Assessment, evaluation and forecasting } \\
\text { of the current and future potential }\end{array}$ & $\begin{array}{l}\text { Financial and management accounting } \\
\text { data }\end{array}$ \\
\hline \multicolumn{4}{|c|}{ Management analysis in marketing } \\
\hline Marketing & Marketing processes & $\begin{array}{l}\text { Assessment, evaluation and forecast of resources, } \\
\text { costs and results of marketing activity }\end{array}$ & Marketing research data \\
\hline
\end{tabular}




\begin{tabular}{llll}
\hline Management analysis of competition & & \\
\hline Competition & $\begin{array}{l}\text { Competitive advantages, } \\
\text { specific characteristics of } \\
\text { competitors }\end{array}$ & $\begin{array}{l}\text { Assessment, evaluation and forecast of competitive } \\
\text { positions }\end{array}$ & $\begin{array}{l}\text { Competitive intelligence data, } \\
\text { accounting and financial reporting data }\end{array}$ \\
\hline Strategic management analysis & $\begin{array}{l}\text { Assessment and evaluation of strategy, monitoring } \\
\text { and adjustment }\end{array}$ & $\begin{array}{l}\text { All kinds of financial and management } \\
\text { accounting data }\end{array}$ \\
\hline $\begin{array}{l}\text { Corporate development } \\
\text { strategy }\end{array}$ & & &
\end{tabular}

Source:[6]

Table 2

The innovation component of the Balanced Scorecard

\begin{tabular}{|c|c|c|c|c|}
\hline $\begin{array}{l}\text { Key issue of Balanced Scorecard innovation } \\
\text { component }\end{array}$ & $\begin{array}{l}\text { Strategic goal of } \\
\text { innovation process }\end{array}$ & $\begin{array}{l}\text { Innovation process } \\
\text { indicator }\end{array}$ & Target value & $\begin{array}{l}\text { Strategic innovation } \\
\text { event }\end{array}$ \\
\hline \multirow{6}{*}{$\begin{array}{l}\text { What innovation goals should be set to implement } \\
\text { objectives of subsequent operational process, } \\
\text { after-sale service, customers and financial process? }\end{array}$} & - & - & - & - \\
\hline & - & - & - & - \\
\hline & - & - & - & - \\
\hline & - & - & - & - \\
\hline & - & - & - & - \\
\hline & - & - & - & - \\
\hline
\end{tabular}

Source:Authoring

Table 3

Some common metrics of Balanced Scorecard innovation component

\begin{tabular}{|c|c|}
\hline Strategic goal of innovation process & Metric \\
\hline $\begin{array}{l}\text { Revealing clients' needs, which are acceptable } \\
\text { for the company, for producing new goods and } \\
\text { services, which would be of great value } \\
\text { for customers in the future }\end{array}$ & $\begin{array}{l}\text { Customers' preferences which are acceptable for the company, concerning the possibility to produce } \\
\text { new goods and services; } \\
\text { Ranking each type of customers' preferences, which are acceptable for the company, concerning } \\
\text { the possibility to produce new kinds of goods and services; } \\
\text { Estimated volume of the market of new goods and services to be produced; } \\
\text { Tentative prices for new kinds of goods and services to be produced }\end{array}$ \\
\hline $\begin{array}{l}\text { Use acceptable innovations to offer goods and } \\
\text { services that will enable the company to stay ahead } \\
\text { of competitors }\end{array}$ & $\begin{array}{l}\text { The number of working versions of brand new goods or services developed before their were } \\
\text { released in the market; } \\
\text { Development time of brand new kinds of goods and services; } \\
\text { Satisfaction degree of customers' wants concerning brand new kinds of goods and services }\end{array}$ \\
\hline $\begin{array}{l}\text { Profound research into brand new kinds of goods } \\
\text { and services creating value for customers }\end{array}$ & $\begin{array}{l}\text { The number of brand new kinds of goods and services; } \\
\text { The share of brand new kinds of goods and services in total sales; } \\
\text { Launch of a new kind of goods against a planned or rival product }\end{array}$ \\
\hline $\begin{array}{l}\text { In-depth research into opportunities for using } \\
\text { the existing technological processes to produce } \\
\text { the next generation goods and services }\end{array}$ & $\begin{array}{l}\text { Capability of production process; } \\
\text { The number of kinds of the next generation goods and services that can be produced using } \\
\text { the existing technological processes }\end{array}$ \\
\hline $\begin{array}{l}\text { Purposeful development of new kinds of goods } \\
\text { and services to promote them in the market }\end{array}$ & $\begin{array}{l}\text { The pace at which new kinds of goods and services are promoted in the market; } \\
\text { The share of new kinds of goods and services which instantly met customers' expectations; } \\
\text { Losses from sales of new kinds of goods and services with the delayed release due to the correction } \\
\text { of the initial project drawbacks; } \\
\text { Break-even time }\end{array}$ \\
\hline
\end{tabular}

Source:Authoring

Please cite this article as: Krylov S.I. Integrated Management Analysis of Innovation: A Conceptual and Methodological Framework. 


\section{Table 4}

The system of key indicators of integrated management analysis of innovation

\begin{tabular}{|c|c|c|c|}
\hline \multirow[t]{2}{*}{ Indicator } & \multicolumn{3}{|c|}{ Application by phase of innovation } \\
\hline & $\begin{array}{l}\text { Creation } \\
\text { of innovation }\end{array}$ & $\begin{array}{l}\text { Adoption } \\
\text { of innovation }\end{array}$ & Outcome \\
\hline 1. Indicators of innovation analysis & + & + & + \\
\hline 1.1. Progressiveness of innovation & + & - & - \\
\hline 1.2. Scientific and technological level & - & + & - \\
\hline 1.3. Innovation activity & - & - & + \\
\hline 1.4. Commercial demand for innovation & + & - & - \\
\hline 1.5. Innovation Incentives & - & - & + \\
\hline 2. Indicators of competitive analysis: & + & + & + \\
\hline 2.1. Competitiveness & - & - & + \\
\hline 2.2. Innovation intensity & + & + & - \\
\hline 2.3. Process innovation density & - & - & + \\
\hline 2.4. Technological dependence & - & + & - \\
\hline 2.5. Legal protection of innovation & - & - & + \\
\hline 2.6. Time to create innovation & + & - & - \\
\hline 3. Indicators of market analysis: & + & + & + \\
\hline 3.1. Comprehensive development of product innovation & - & - & + \\
\hline 3.2. Use of advanced technology & + & - & - \\
\hline 3.3. Demand for process innovation & - & - & + \\
\hline 3.4. Versatile applicability & - & + & - \\
\hline 4. Indicators of investment analysis: & + & + & - \\
\hline 4.1. Financial aid of the State & + & + & - \\
\hline 4.2. Debt dependence & + & + & - \\
\hline 4.3. Financial independence & + & + & - \\
\hline 4.4. Financial indicator of technological dependence & + & + & - \\
\hline 4.5. Foreign equity & + & + & - \\
\hline 4.6. National equity & + & + & - \\
\hline
\end{tabular}

Source:Authoring

\section{References}

1. Horngren C., Foster G., Datar S.M. Cost Accounting: A Managerial Emphasis. Prentice Hall, 2000,906 p.

2. Drury C. Cost and Management Accounting: An Introduction. Thomson Learning, 2003, 552 p.

3. Bakanov M.I., Mel'nik M.V., Sheremet A.D. Teoriia ekonomicheskogo analiza [Theory of economic analysis]. Moscow, Finansy i Statistika Publ., 2005, 536 p.

4. Kovalev V.V. Finansovyi menedzhment: teoriia i praktika [Financial management: Theory and practice]. Moscow, Prospekt Publ., 2007, 1024 p.

5. Savitskaia G.V. Ekonomicheskii analiz [Economic analysis]. Moscow, INFRA-M Publ., 2013, 649 p.

6. Ilyshev A.M., Karavaeva, A.V. [Identification of integrated management analysis amid turbulence and megacompetition]. Problemy sovremennoi ekonomiki = Problems of Modern Economics, 2007, no. 4. URL: http://www.m-economy.ru/art.php?nArtld=1636 (In Russ.)

7. Kaplan R.S., Norton D.P. The Balanced Scorecard: Measures That Drive Performance. Harvard Business Review, 1992, vol. 70, iss. 1, pp. 71-79.

Please cite this article as: Krylov S.I. Integrated Management Analysis of Innovation: A Conceptual and Methodological Framework. 
8. Kaplan R.S., Norton D.P. Sbalansirovannaya sistema pokazatelei. Ot strategii k deistviyu [The Balanced Scorecard: Translating Strategy into Action]. Moscow, Olymp-Biznes Publ., 2006, 320 p.

9. Kaplan R.S., Norton D.P. The Strategy-Focused Organization: How Balanced Scorecard Companies Thrive in the New Competitive Environment. Harvard Business School Press, 2001, 416 p.

10. Kaplan R.S., Norton D.P. Strategy Maps: Converting Intangible Assets into Tangible Outcomes. Harvard Business School Press, 2003, 512 p.

11. Kaplan R.S., Norton D.P. The Execution Premium: Linking Strategy to Operations for Competitive Advantage. Harvard Business School Press, 2008, 320 p.

12. Brown M.G. Beyond the Balanced Scorecard. Improving Business Intelligence with Analytics. Productivity Press, 2007, 233 p.

13. Friedag H.R., Schmidt W. Sbalansirovannaya sistema pokazatelei: rukovodstvo po vnedreniyu [Balanced Scorecard: Mehr als ein Kennzahlensystem]. Moscow, Omega-L Publ., 2006, 267 p.

14. Horvath und Partner GmbH. Vnedrenie sbalansirovannoi sistemy pokazatelei [Balanced Scorecard Unsetzen]. Moscow, Alpina Biznes Buks Publ., 2006, 478 p.

15. Maisel L.S. Performance Management: the Balanced Scorecard Approach. Journal of Cost Management, 1992, vol. 6, no. 2, pp. 47-52.

16. Olve N.-G., Roy J., Wetter M. Sbalansirovannaya sistema pokazatelei. Prakticheskoe rukovodstvo po ispolzovaniyu [Performers Drivers. A Practical Guide to Using the Balanced Scorecard]. Moscow, Vil'yams Publ., 2006, 304 p.

17. Rampersad H. Universal'naya sistema pokazatelei. Kak dostigat' resultatov, sokhranyaya tselostnost' [Total Performance Scorecard. Redefining Management to Achieve Performance with Integrity]. Moscow, Alpina Biznes Buks Publ., 2006, 352 p.

18. Krylov S. Applied Strategic Innovative Analysis: Theoretical Aspects. European Journal of Business and Social Sciences, 2014, vol. 3, no. 3, pp. 113-133.

19. Krylov S. Applied Strategic Analysis as Further Balanced Scorecard Concept Development. Proceedings of the 11 th Eurasia Business and Economics Society (EBES) Conference. September 12-14, 2013. Yekaterinburg, Institute of Economics of Ural Branch Ras Publ., 2013, pp. 35-42.

20. Krylov S.I. Theoretical Aspects of Economic Balanced Scorecard Analysis. Asian Journal of Finance \& Accounting, 2014, vol. 6, no. 1, pp. 90-109. URL: https://doi.org/10.5296/ajfa.v6i1.4821

21. Twiss B.C. Upravlenie nauchno-tekhnicheskimi novovvedeniyami [Managing Technological Innovation]. Moscow, Ekonomika Publ., 1989, 271 p.

22. Szántó B. Innovatsiya kak sredstvo ekonomicheskogo razvitiya [Innováció a gazdaság fejlesztésének eszköze]. Moscow, Progress Publ., 1990, 295 p.

23. Levinson A. Ekonomicheskie problemy upravleniya nauchno-tekhnicheskim progressom: opyt sistemnogo analiza [Economic problems of managing the scientific-technical progress: experience in the system-oriented analysis]. Moscow, Ekonomika Publ., 1973, 315 p.

24. Schumpeter J.A. Teoriya ekonomicheskogo razvitiya [Theorie der wirtschaftlichen Entwicklung: eine untersuchung über unternehmergewinn, kapital, kredit, zins und den konjunkturzyklus]. Moscow, EKSMO Publ., 2007, 864 p.

25. Ilysheva N., Krylov S. Integrated Analysis for Innovation Management in a Company. Proceedings of the 10 th International Days of Statistics and Economics Conference. September 8-10, 2016. Prague, University of Economics Publ., 2016, pp. 663-671.

Please cite this article as: Krylov S.I. Integrated Management Analysis of Innovation: A Conceptual and Methodological Framework. 
26. Ilysheva N., Krylov S. Integrated Management Analysis of Innovation Performance in Conditions of Globalization. Proceedings of the 16th Globalization and Its Socio-Economic Consequences Conference. October 5-6, 2016. Rajecke Teplice, University of Zilina, 2016, pp. 734-740.

27. Kovalev V.V. Finansovyi uchet $i$ analiz: kontseptual'nye osnovy [Financial accounting and analysis: Conceptual framework]. Moscow, Finansy i Statistika Publ., 2004, 720 p.

28. Saaty T.L. The Analytic Hierarchy Process: Planning, Priority Setting, Resource Allocation. McGraw-Hill, 1993, $287 \mathrm{p}$.

29. Ilyshev A.M., Ilysheva N.N., Selevich T.S. Strategicheskii konkurentnyi analiz v tranzitivnoi ekonomike Rossii [Strategic competitive analysis in the transition economy of Russia]. Moscow, Finansy i Statistika, INFRA-M Publ., 2010, 480 p.

30. Pearce II J.A., Robinson R.B. Strategic Management: Formulation, Implementation, and Control. McGraw-Hill, 2011, $992 \mathrm{p}$.

31. Christensen C.M., Raynor M.E. The Innovator's Solution: Creation and Sustaining Successful Growth. Harvard Business School Press, 2003, 305 p.

32. Grant R.M. Contemporary Strategy Analysis. John Willey \& Sons, 2015, 842 p.

33. Hamel G. The Why, What, and How of Management Innovation. Harvard Business Review, 2006, vol. 84, iss. 2, pp. 72-84.

\section{Conflict-of-interest notification}

I, the author of this article, bindingly and explicitly declare of the partial and total lack of actual or potential conflict of interest with any other third party whatsoever, which may arise as a result of the publication of this article. This statement relates to the study, data collection and interpretation, writing and preparation of the article, and the decision to submit the manuscript for publication. 